\title{
THE EFFECT OF RAW MATERIALS ON SOME PHYSICAL PROPERTIES OF OSUN STATE CERAMIC TILES
}

\author{
OLURANTI ABIOLA ${ }^{* 1}$, ADEKOLA OKE ${ }^{2}$, BABATUNDE OMIDIJI ${ }^{2}$, DARE \\ $\operatorname{ADETAN}^{2}$ \\ ${ }^{I}$ Department of Automotive Engineering, Elizade University, Ilara-Mokin, Ondo State, \\ Nigeria \\ ${ }^{2}$ Department of Mechanical Engineering, Obafemi Awolowo University, Ile-Ife, 22005, \\ Nigeria
}

\begin{abstract}
The study evaluates the effect of ceramic raw materials on the physical properties of ceramic tiles with a view to determine the tiles with the best material blend. Ten different blends of clay - feldspar - silica was used to produce ceramic samples. The results show that sample with $60 \%$ clay, $30 \%$ feldspar and $10 \%$ silica have the best water absorption $(10.43 \%)$ and apparent porosity $(22.77 \%$ ); while sample with $60 \%$ clay, $20 \%$ feldspar and $20 \%$ silica exhibits the highest apparent relative density of 2.79 . Sample with $50 \%$ clay, $40 \%$ feldspar and $10 \%$ silica possesses the best bulk density of $1.43 \mathrm{~g} / \mathrm{cm}^{3}$. Conclusively, the ceramic sample produced can be useful in the production of wall tiles.
\end{abstract}

Keywords: clay, feldspar, silica sand, triaxial blend, physical properties

\section{INTRODUCTION}

Ceramic tiles are clay-based, triaxial blend products commonly used to cover floors and walls [1-4]. It is primarily a hygiene product made of porous body with a coating of white or colored glaze extensively used in living room, bathrooms, kitchens, medical centers, laboratories, schools, public conveniences, and shopping malls [2]. Meanwhile, ceramics are inorganic, nonmetallic crystalline materials comprising metal, nonmetal or metalloid atoms primarily held by ionic and covalent bonds [5-7]. According to Iyasara et al. [8] ceramics are inorganic compounds made by heating a blend of three silicate clay minerals: clay, silica sand and Feldspar, each of which reacts upon one another when subjected to appropriate high temperature.

Clay provides the plasticity to ceramic articles during firing while the feldspar act as glazing material, helps in the liquid (flux) formation and reduces the porcelain porosity, the silica sand serves as a filler that gives strength and hardness to the ceramic body [2, 9]. Several studies have also shown ball clay, bentonite, limestone, talc $[2,10$, 11] and additives such as steel slag waste, rutile, glass, rice husk ash, granite sawing waste, bone ash, coal fly ash, steel dust etc. as useful raw materials for ceramic tiles production $[12,13]$.

Though several materials can be used for the production of ceramic tiles, Adnan et al., [14] presented clay as the prime raw material whose properties has great effect on the properties of ceramic tiles. Research have also proved that kaolin, quartz and feldspar are the most commonly used materials $[1-3,13,15]$.

\footnotetext{
${ }^{*}$ Corresponding author, email: abiolaolurantiadetunji@yahoo.com

(C) 2021 Alma Mater Publishing House
} 
Meanwhile, studies have shown that the properties of this ceramic raw materials vary from location to location. This is evident in the work of Badmus and Olatinsu [16] which investigated the geophysical and chemical properties of clay samples collected from three different locations in the same deposit located in Lakiri village in Ogun State and concluded that the samples differ in properties. This was corroborated by El Nouhy [2] who reported that the variation in the properties of clay minerals with the location is due to the difference in particle size, particle size distribution and human and environmental factors. Hence, this work seeks to investigate the effect of ceramic raw materials on the physical properties of ceramic tiles.

\section{EXPERIMENTAL SETUP}

\subsection{Materials and sources}

The clay mineral used in this study was kaolinite clay [17], collected from Ipetumodu, headquarters of the Ife North Local Government area of Osun State, Nigeria. Silica sand was collected from the Isasa River; the river serves as the boundary between the Ayedaade and Ife North Local Government areas of Osun State, Nigeria. Feldspar was collected from Osogbo, the capital of Osun State, Nigeria. The three raw materials collected were beneficiated separately as specified by Abiola et al. [18].

\subsection{Preparation of materials}

The ceramic raw materials were homogenously mixed together to produce a more chemically and physically homogenous material for forming tiles. The mixing ratios for the ceramic raw materials were varied because of the various contradictions recorded regarding the best/optimum mixing ratio for ceramic materials $[6,9,19-22]$.

A 10-step tri-axial blending chart proposed by Norsker and Danisch [23] was adopted to predict the mixing ratio of the ceramic raw materials. The chart has sixty-six possible blends of clay, feldspar and silica sand as shown in Figure 1, but only the ceramic blends with clay - feldspar - silica sand ratios of 5:4:1, 5:3:2, 5:2:3, 5:1:4, 6:3:1, $6: 2: 2,6: 1: 3,7: 2: 1,7: 1: 2$ and $8: 1: 1$ by weight, and designated as blend $\mathrm{A}, \mathrm{B}, \mathrm{C}$, up to J respectively was adopted. Thirty number blends that comprise less than three materials were neglected since ceramic is described as a triaxial blend product $[1,8,9,13,21,24]$. Twenty-six other blends which have less than $50 \%$ clay proportion were also ignored since clay is the predominant material in ceramic tile production $[1,2,6,7,15,24-27]$.

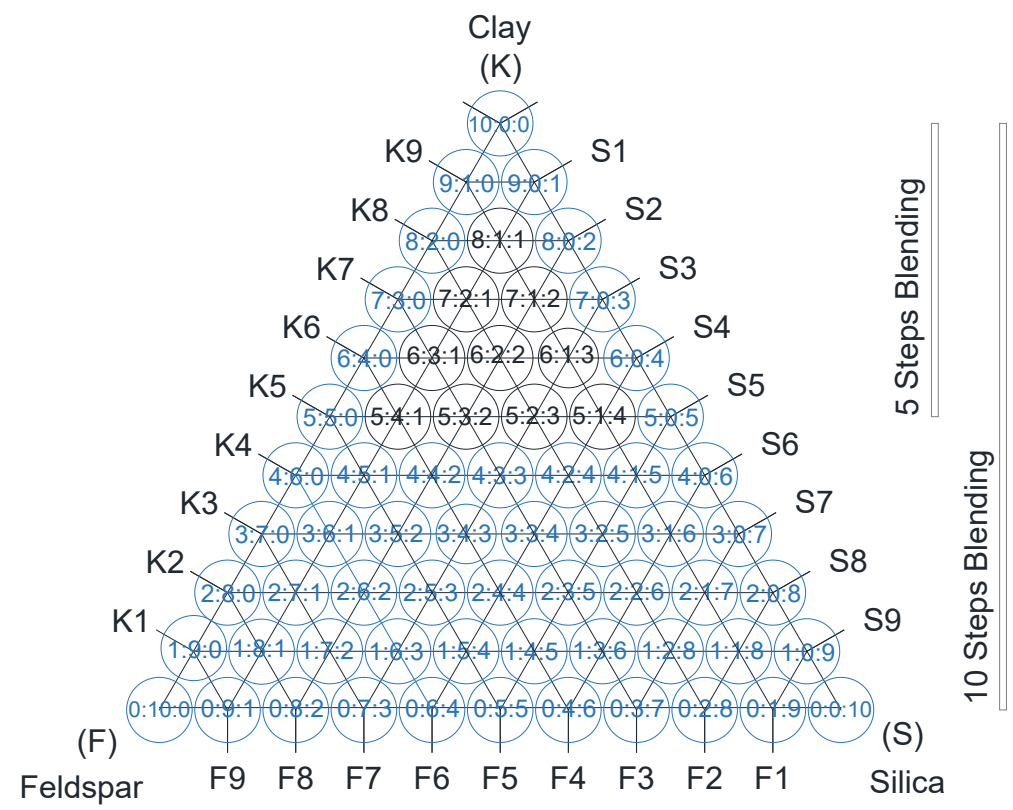

Fig. 1. 10 steps triaxial blending chart.

Ceramic samples were made from each blend, A - J of the ceramic materials by compacting them at $40 \mathrm{MPa}$ pressure as specified by Bresciani et al. [28] to recommended size for physical property test sample, $50 \times 15 \times 15$ mm. 
After forming, the samples were dried by convection in an open laboratory drying oven (model DHG-9101-2A manufactured by Searchtech Instrument) where heated air was circulated around the ceramic samples. The air around the samples was kept at $95^{\circ} \mathrm{C}$ to remove the water content since water is expected to evaporate from ceramic mixture below $100^{\circ} \mathrm{C}$. The materials were kept under this condition for a period of 20 hours following the method of Br.MSME-DI [29]. This drying process is expected to prevent differential shrinkage, warping, cracking and distortion of the eventual product.

Prior to firing, the ceramic samples were heat-treated in the laboratory drying oven at a temperature of $300^{\circ} \mathrm{C}$ in line with recommendation of Br.MSME-DI [29] to provide additional drying, vaporize or decompose organic additives and other impurities, as well as to remove residual, crystalline, and chemically bound water.

As recommended by Br.MSME-DI [29], the ceramic samples were kept in the kiln for 20 hours while the temperature of $300^{\circ} \mathrm{C}$ was held constant. After this period, the ceramic samples were brought out of the kiln and allowed to cool normally at ambient temperature and then fired in a furnace (model XD-1700M manufacturer by Zhengzhou Brother Furnace Company, China).

The experimental firing temperature of $1300^{\circ} \mathrm{C}$ was employed since Idowu, (2014) used the same to produce ceramic tiles from raw materials collected from Nigeria.

The samples were held at the respective firing temperatures for about 1-hour soaking time to ensure equalization of temperature throughout the cross-section of the samples $[30,31]$. Thereafter, the samples were allowed to cool in the kiln for 18 hours in line with the work of Br.MSME-DI [29].

\subsection{Physical properties test}

After cooling, the ceramic tiles were off-loaded from the kiln and subjected to water absorption, apparent porosity, and apparent relative density test according to ISO 10545-3 [32] guidelines.

The water absorption was calculated from equation (1):

$$
A_{w}=\frac{m_{2}-m_{1}}{m_{1}} \cdot 100 \%
$$

where $A_{w}$ is water absorption (\%), $m_{1}$ is the average mass of the dry samples in gram (g), and $m_{2}$ is the average mass of the wet samples in gram $(\mathrm{g})[32]$.

Apparent porosity was calculated from equation (2):

$$
P_{a}=\frac{m_{2}-m_{1}}{m_{2}-m_{3}} \cdot 100 \%
$$

where $P_{a}$ is the apparent porosity (\%), $m_{1}$ is the average mass of the dry samples in gram $(\mathrm{g}), m_{2}$ is the average mass of the wet samples in gram $(\mathrm{g})$, and $m_{3}$ is the average mass of the suspended samples impregnated by boiling water in gram $(\mathrm{g})$ [32].

Meanwhile, apparent relative density was calculated using equation (3) [32]:

$$
R D_{a}=\frac{m_{1}}{m_{1}-m_{3}}
$$

where $R D_{a}$ is the apparent relative density, $m_{1}$ and $m_{3}$ are the same as in equation (2) [32].

Bulk density was determined using equation (4) as:

$$
B D=\frac{m_{1}}{V}
$$

where $B D$ is the bulk density, in $\mathrm{g} / \mathrm{cm}^{3}, m_{1}$ is the average mass of the dry samples in gram (g), and $V$ is the exterior volume of the sample, in $\mathrm{cm}^{3}$ [32]. 


\section{RESULTS AND DISCUSSION}

\subsection{Water absorption (Aw)}

The results of the water absorption (Aw) tests shown in Table 1 reveal that water absorption generally increased with reduced feldspar content and increased silica sand content. Sample "E" with $60 \%$ clay, $30 \%$ feldspar and $10 \%$ silica sand have the best water absorption (10.43\%). This is due to the ability of the feldspar materials to melt at high temperature and act as a fluxing agent, filling up the pores within the ceramic article [2].

Table 1. Physical properties of samples produced from blend kaolin, feldspar and silica sand.

\begin{tabular}{|c|c|c|c|c|c|}
\hline Samples & Ratio & $\begin{array}{c}\text { Aw } \\
(\%)\end{array}$ & $\begin{array}{c}\mathrm{P}_{\mathrm{a}} \\
(\%)\end{array}$ & Rda & $\begin{array}{c}\mathrm{BD} \\
\left(\mathrm{g} / \mathrm{cm}^{3}\right)\end{array}$ \\
\hline A & $(5: 4: 1)$ & 13.14 & 25.95 & 2.67 & 1.43 \\
\hline B & $(5: 3: 2)$ & 13.18 & 25.9 & 2.65 & 1.39 \\
\hline C & $(5: 2: 3)$ & 13.86 & 27.05 & 2.68 & 1.37 \\
\hline D & $(5: 1: 4)$ & 14.06 & 27.95 & 2.76 & 1.35 \\
\hline E & $(6: 3: 1)$ & 10.43 & 22.77 & 2.83 & 1.42 \\
\hline F & $(6: 2: 2)$ & 10.88 & 23.3 & 2.79 & 1.41 \\
\hline G & $(6: 1: 3)$ & 11.38 & 24.83 & 2.9 & 1.41 \\
\hline H & $(7: 2: 1)$ & 11.56 & 22.52 & 2.51 & 1.39 \\
\hline I & $(7: 1: 2)$ & 11.92 & 22.93 & 2.5 & 1.38 \\
\hline J & $(8: 1: 1)$ & 11.9 & 22.03 & 2.38 & 1.36 \\
\hline
\end{tabular}

\subsection{Apparent porosity (Pa)}

The results of the apparent porosity $(\mathrm{Pa})$ tests (see Table 1 ) reveal that apparent porosity generally increased with reduced feldspar content and increased silica sand content. Sample "E" with $60 \%$ clay, $30 \%$ feldspar and $10 \%$ silica sand have the best apparent porosity $(22.77 \%)$. This is also due to the ability of the feldspar to decompose at high temperature and act as a flux, filling up the pores within the ceramic article [2].

\subsection{Apparent relative density (RDa)}

The result in Table 1 shows an inverse relationship between the apparent relative density of the ceramic article and the clay material contained within the mixture. High clay content results in low apparent relative density of the article. While sample F with $60 \%$ clay, $20 \%$ feldspar and 20\% silica sand revealed the highest apparent relative density of 2.79 ; sample J with $80 \%$ clay, $10 \%$ feldspar and $10 \%$ silica sand have the lowest apparent relative density of 2.38. Increased plasticity of the ceramic sample due to increased clay may be responsible for the increased apparent relative density [2].

\subsection{Bulk density (BD)}

The result shows an indirect relationship between the bulk density of the ceramic article and the silica sand contained within the mixture which is contrary to the deduction of El Nouhy, [2] and El-Fadaly, [22]. Increasing silica sand shows a slight decrease in the bulk density of the article. Sample A with $50 \%$ clay, $40 \%$ feldspar and $10 \%$ silica sand revealed the highest bulk density $\left(1.43 \mathrm{~g} / \mathrm{cm}^{3}\right)$ while sample D $(50 \%$ clay, $10 \%$ feldspar and 40 $\%$ silica sand) revealed the lowest bulk density of $1.35 \mathrm{~g} / \mathrm{cm}^{3}$. This may be due to high silica sand content in the clay used in this study [19] and the ability of silica sand to give strength and support to a ceramic body and reduce its tendency to warp or distort when fired at high temperature [2].

\section{CONCLUSIONS}

The different raw materials have their specific importance as a constituent in the ceramic blend which proved them as a material not to be discarded. Since increase feldspar help to reduce water absorption which is considered the most important physical property of any ceramic tiles; sample ' $E$ ' with $60 \%$ clay, $30 \%$ feldspar and $10 \%$ silica sand produced the tiles with the best physical properties.

Therefore, ceramic sample produced from Osun State raw materials demonstrate its usefulness in the production of wall tiles since the water absorption meets the ISO standard. 


\section{REFERENCES}

[1] Irabor, P.S.A., Jimoh, S.O., Omowumi, O.J., Ceramic raw materials development in Nigeria, International Journal of Scientific and Technological Research, vol. 3, no. 9, 2014, p. 275-287.

[2] El Nouhy, H.A., Assessment of some locally produced Egyptian ceramic wall tiles, Housing and Building National Research Center Journal, vol. 9, 2013, p. 201-209.

[3] Martín-Márquez, J., Rincón, J.Ma., Romero, M., Effect of firing temperature on sintering of porcelain stoneware tiles, Ceramics International, vol. 34, 2008, p. 1867-1873.

[4] Iqbal, Y., Lee, W.E., Microstructural evolution in triaxial porcelain, Journal of American Ceramic Society, vol. 83 , no. 12,2000 , p. 3121-3127.

[5] https://eippcb.jrc.ec.europa.eu/sites/default/files/2019-11/cer_bref_0807.pdf (9.09.2019).

[6] Adindu, C.I., Moses, J., Thaddeus, C.A., Tse, D.T., Exploring ceramic raw materials in Nigeria and their contribution to nation's development, American Journal of Engineering Research, vol. 3, no. 9, 2014, p. 127-134.

[7] Solanki, K.M., Shah, S.R., Analysis of drying process in ceramic tiles industries, International Journal of Advance Ideals in Education, vol. 2, no. 3, 2016, p. 409-418.

[8] Iyasara, A.C., Joseph, M., Azubuike, T.C., The use of local ceramic materials for the production of dental porcelain, American Journal of Engineering Research, vol. 3, no. 9, 2014, p. 135-139.

[9] Idowu, I.O., Production of vitrified porcelain tiles using local raw materials from south western Nigeria, Journal of Emerging Trends in Engineering and Applied Sciences, vol. 5, no. 6, 2014, p. 421-428.

[10] Abdel, A.D.A., Aly, M.H., Salem, I.A., Abead, S.A., Effect of air blast furnace slag and $\gamma$-alumina content on dielectric properties and physical properties of porcelain insulators, Physics and Materials Chemistry, vol. 3, no. 2, 2015, p. 30-36.

[11] Kamseu, E., Leonelli, C., Boccaccini, D.N., Veronesi, P., Miselli, P., Pellacani, G., Melo, U.C., Characterisation of porcelain compositions using two china clays from Cameroon, Ceramics International, vol. 33, 2007, p. 851-857.

[12] Mohd, K., Hasmaliza, M., Effect of rutile on modulus of rupture in ceramic glaze, Procedia Chemistry, vol. 19, 2016, p. 10-14.

[13] Teo, P.T., Seman, A.A., Basu, P., Sharif, N.M., Characterization of EAF steel slag waste: the potential green resource for ceramic tile production, Procedia Chemistry, vol. 19, 2016, p. 842-846.

[14] Adnan, M., Sazzad, H.M., Fakhrul, I.M., Potential of locally available clay as raw material for traditionalceramic, Journal of Chemical Engineering, vol. 26, no. 1, 2011, p. 34-37.

[15] Misra, S.N., Machhoya, B.B., Savsani, R.M., Thermo physical characteristics of vitrified tile polishing waste for use in traditional ceramics-an initiative of CGCRI, Naroda centre, International Journal of Modern Physics: Conference Series, vol. 22, 2013, p. 118-133.

[16] Badmus, B.S., Olatinsu, O.B., Geophysical evaluation and chemical analysis of kaolin clay deposit of Lakiri village, southwestern Nigeria, International Journal of Physical Sciences, vol. 4, no. 10, 2009, p. 592-606.

[17] Oke, A.O., Omidiji, B.V., Investigation of same moulding properties of a Nigeria clay-bonded sand, Archives of Foundry Engineering, vol. 16, no. 3, 2016, p. 71-76.

[18] Abiola, O.A., Oke, A.O., Omidiji, B.V., Adetan, D.A., The effect of beneficiation on some properties of Osun State ceramic raw materials, Journal of Casting and Materials Engineering, vol 3, no. 3, 2019, p. 62-66.

[19] Braganca, S.R., Bergmann, C.P., Traditional and glass powder porcelain: technical and microstructure analysis, Journal of European Ceramic Society, vol. 24, no. 8, 2004, p. 2383-2388.

[20] Amoros, J.L., Orts, M.J., Garcia-Ten, J., Gozalbo, A., Sanchez, E., Effect of the green porous texture on porcelain tile properties, Journal of the European Ceramic Society, vol. 27, 2007, p. 2295-2301.

[21] El-Fadaly, E., Characterization of porcelain stoneware tiles based on solid ceramic wastes, International Journal of Science and Research, vol. 4, no. 1, 2015, p. 602-608.

[22] Martín-Márquez, J., Rincon, J., Ma., Romero, M., Mullite development on firing in porcelain stoneware bodies, Journal of the European Ceramic Society, vol. 30, no. 7, 2010, p. 1599-1607.

[23] Norsker, H., Danisch, J., Glazed for the self-reliant potter, Ed. Vieweg and Sohn, Braunschweig, Germany, 1993.

[24] Soni, A., Mathur, R., Kumar, K., Study on particle size distribution and its effects on shrinkage, porosity and bulk density of tri-axial porcelain tiles, Indian Journal of Research, vol. 4, no. 5, 2015, p. 58-60.

[25] El Ouahabi1, M., Daoudi, L., De Vleeschouwer, F., Bindler, R., Fagel, N., Potentiality of clay raw materials from northern Morocco in ceramic industry: Tetouan and Meknes areas, Journal of Minerals and Materials Characterization and Engineering, vol. 2, no. 3, 2014, p. 145-159.

[26] Manfredini, T., Hanuskova, M., Natural raw materials in "traditional" ceramic manufacturing, Journal of the University of Chemical Technology and Metallurgy, vol. 7, no. 4, 2012, p. 465-470.

[27] Murray, H.H., Applied clay mineralogy today and tomorrow, Clay Minerals, vol. 34, 1999, p. 39-49. 
[28] Bresciani, A., Ricci, C., Imola, S., Innovative process for ceramic tile manufacturing by double pressing with continuous precompaction, Castlelon, vol. 1, 2004, p. 49-60.

[29] http://www.msmedikolkata.gov.in/pp/ceramicglazedtiles.pdf (13.01.2020).

[30] Abeid, S., Park, S.E., Suitability of vermiculite and rice husk ash as raw materials for production of ceramic tiles, International Journal of Materials Science and Applications, vol. 7, no. 2, 2018, p. 39-48.

[31] Ashby, M.F., Materials selection in mechanical design, Third Ed. Pergamon Press, Butterworth-Heinemann Linacre House, Jordan Hill, Oxford, 2005.

[32] http://www.norfloor.no/media/wysiwyg/DIY/ISO 10545-2.pdf (13.01.2020). 